\title{
SUFISM AND RELIGIOUS PRACTICES IN MODERN LIFESTYLE
}

\author{
Suraiya IT. \\ UIN Ar-Raniry Banda Aceh \\ Email: ayathaib@aol.com \\ Syamsul Rijal \\ UIN Ar-Raniry Banda Aceh \\ Email: literasi.syamsulrijal@ar-raniry.ac.id \\ Zaenuddin Hudi Prasojo \\ IAIN Pontianak \\ Email: zaestain@yahoo.com
}

\begin{abstract}
Along with scientific development and technological growth which have created a lot of convenience to mankind there have also raised a deep cynicism towards the religious and spiritual aspects of life. Value crisis of humanity marked by the crisis of spirituality increased. Many societies are facing deep crisis. This condition makes the world vulnerable to violence and conflicts. Therefore, modern world society has been challenged to to be more attentive than before to deal with religious and spiritual values. This paper asserts that religion continues to be an important since it combines both personal and public character. Social problems faced by the modern world society such as cultural diversity, environmental preservation, economic equity, and conflict resolution are theologically reflected within the teaching of Islam. Sufism as a form of Islamic spiritualities offers some applicable answers for this phenomenon. In addition, characteristic of Sufism (mysticism) is commonly well known in almost all religions. Sufism cherishes from the
\end{abstract}


private sphere into a popular Islamic culture. This research would like to see how the phenomenon of spiritual movement in the dimension of Sufism has a real powerful to improve social problem of the modern world.

Perkembangan sains dan teknologi tidak hanya membawa kemudahan bagi hidup manusia, tapi juga memenuhinya dengan sikap sinisme terhadap agama dan aspek spiritual lainnya. Muncul krisis nilai kemanusian yang ditopang oleh krisis spiritual. Lebih dari itu, ada krisis lain, semisal krisis ekologi, krisis moral, kekerasan, kemiskinan, dan krisis kesehatan yang kerap menyertai kegalauan masyarakat modern. Hal itulah yang kemudian menghadirkan bentukbentuk kekerasan atau konflik yang belum pernah dialami sebelumnya. Meski demikian, agama tetap berperan penting karena kemampuannya menyentuh sisi personal sekaligus sisi sosial seseorang atau sebuah masyarakat. Isu-isu seperti keragaman budaya, preservasi lingkungan, kesetaraan ekonomi, dan resolusi konflik, diakomodasi dalam ajaranajaran agama (Islam). Sufisme, sebagai salah satu bentuk pemikiran untuk merekonstruksi spiritualitas menjadi penting sebagai upaya menemukan jawaban atas problemproblem tersebut. Sufisme bisa berkembang dari ruang privat ke ruang-ruang publik masyarakat modern yang materialistis. Penelitian ini ingin melihat bagaimana gerakan spiritual dalam dimensi-dimensi tasawuf mampu mengatasi permasalahan sosial keagamaan yang terjadi pada masyarakat modern.]

Keywords: Sufism, spirituality, bumanity, modernity, science, technology.

\section{Introduction}

The Development of Science and Technology have brought not only a lot of convenience to mankind but also a deep cynicism towards the religious and spiritual aspects of life. There emerges value crisis of humanity marked by the crisis of spirituality. Multi-dimensional crisis, ecological crisis, violence, morals, crime, 
social inequalities, poverty and diseases haunt modern society. ${ }^{1} \mathrm{We}$ are witnesses of a process, which is based on technological information, and which creates global economy and forms specific world system.

At the same time when many societies are facing deep crisis there is uncertainty about the future, and it creates new crises for the maintenance of religious boundaries. Further complexity is the power that plays religion in the contemporary world. Religion declines in Western societies that force of modernization and secularization. On the contrary, it is very hard to understand the modern world without understanding the major religious traditions and influences that cut across global boundaries and feed into and shape global politics. ${ }^{2}$ This condition makes the world vulnerable to violence and conflicts. Therefore, the global community has to be more vigilant than before to fight this situation with religious values. With the emergence of modern world, religious organizations had to adapt to two circumstances: individualization and pluralism. ${ }^{3}$ The two elements allow the religion to activate itself freely, as private initiative, in the postmodern societies, or as content of national identity. However, religion continues to be an important because religion combines the personal and public character. Clifford Geertz underlines that religion is a system of symbols which acts to establish powerful, pervasive, and long lasting motivations in men by formulating conceptions of a general order of existence and clothing these conceptions with such an aura of factuality that the moods seem uniquely realistic. ${ }^{4}$ According to Geertz, there is no separation between religious and non-religious life for people of religion, because their beliefs

\footnotetext{
${ }^{1}$ Husin Heriyanto, Paradigma Holistik: Dialog Filsafat, Sains, dan Kebidupan Menurut Shadra dan Whitehead, (Jakarta: Teraju, 2003), 1

${ }^{2}$ Malory Nye, Religion the Basics (Routledge: London, 2003), 177.

${ }^{3}$ Peter L Berger, The Sacred Canopy. Elements of a Sociological Theory of Religion (New York: Anchor Books, 1990), 133-135.

${ }^{4}$ Clifford Geertz, "Religion as a Cultural System," in Michael Banton, Anthropological Approach to Study of Religion (London: Tavistock, 1966), 4.
} 
account for all their life activities. ${ }^{5}$ Therefore, religion comes back in the public area as a more or less developed aspect of human action. Religious beliefs and practices have a large impact on the personal lives and influence public life on a daily basis.

Sufistic thought as a form of human-spirituality reconstruction is relevant to answer this phenomenon, because the characteristic of Sufism (mysticism) is common in almost all religions. Understanding Sufism is a foundation of searching for the alternative life problem solution. Sufism develops from the private sphere into a popular Islamic culture. Therefore, Spirituality is a phenomenon that is potentially inherent in humans. Sometimes, spirituality refers to the search for sacred things in life. Sufism is the best way to restore a person to spiritual consciousness through the transcendental dimension. Sufism is also used as a medium to create a peaceful understanding of the reality of the world. Therefore, to understand Sufism one must first to understand the terminology of mysticism. Sufism is sometimes used as a medium to create a peaceful understanding of the reality of the world.

Sufism may also be described as a metaphysical psychology is based on Islamic sources and appropriate for addressing the maladies afflicting the present-day world. Sufism teaches that it is possible for us to see beyond the veils of darkness which enclose our belief systems. Sufism is the voice of peace, co-existence, compassion and equality; a call to universal brotherhood. According to Michael A. Sells, Sufism is one of the most extensive traditions of spirituality in the history of religion. ${ }^{6}$ Sufism also has often defined as Islamic "Mysticism," comprising a set of techniques by which Muslims have sought a direct personal encounter with the divine. ${ }^{7}$ While it is true that Sufism encompasses many mystical elements, the broad social reach that it

\footnotetext{
${ }^{5}$ Ibid.

${ }^{6}$ Michael A. Sells, Early Islamic Mysticism (New York: Paulist Press, 1996).

${ }^{7}$ Damanhuri, Akblak Tasawuf (Banda Aceh: Yayasan Pena, 2010), 3
} 
acquired over centuries of expansion rendered it much more than the path of an esoteric elite. ${ }^{8}$

Movements, practices and teachings of Sufism began to be loved by the community. This phenomenon especially occurs in many urban environments. Sufi approach is relevant for both today's society and questions that will shape humanity's direction in the future. Issues relating to community values, cultural diversity, environmental preservation, economic equity, and conflict resolution are all considered in the teaching of Islam. Various Sufi masters sought to address these issues. Those engaged in Sufi practices are playing their knowledge of tasamuf to many fields as varied as sustainable development, education, therapy, parenting, science and technology, and cross-cultural communication. Disciples of Sufism view services as a means, not an end. Outer work alone cannot resolve the problems that beset humanity, for these problem roots lie in the human heart.

Sayyed Hussein Nasr, as quoted by Amin Syukur ${ }^{9}$, concluded that in recent decade, Sufism has experienced a resurgence in the Muslim world such as Syria, Iran, Turkey, Pakistan, and Southeast Asia. There was a remarkable upsurge of interest in Sufism, especially among educated and modern segments of the urban middle class. According to him, some of the resurrection was related to the increasing activity of Sufi orders, a very active shädhiliyah and ni'matulläh tarekat, for example in Syria and Iran. Moreover, there are also serious attempts to rediscover the minds of great Sufi figures, especially Ibn 'Arabi and using Sufism in addressing the challenges of humanity and spirituality in modern times.

As Islam spread to Asia, and later to Africa, monistic varieties of Sufism in their most sophisticated version the doctrine of the Unity of Being (wabdat al-wnjüd), associated with Ibn 'Arabi, were more compatible with the local conception of immanent

\footnotetext{
8 Ibid,. 5-6.

${ }^{9}$ Amin Syukur, Menggngat Tasannuf(Yogyakarta: Pustaka Pelajar, 1996), 127.
} 
godhead, and easily merged with older local belief and practices. It was however, not anti-Sufi puritans who carried out the struggle for reform of these belief, most of the early reformers were shariaoriented Sufis themselves. ${ }^{10}$

In the early twenty centuries, the Sufi orders had found a new appreciation among the educated. This was partly no doubt a response to the Islamic resurgence and the prominence of increasingly militant groups in many societies. Sufism offered a more irenic discourse, which was more tolerance of nonconformism and more conducive to interfaith harmony, and with was embraced by quite significant sections of the modern middle classes and intellectually more respectable alternative to Islamism. Influential modern thinkers such as Muhammad Iqbal and Abdul Karim Soroush, who both took a highly negative view of popular Sufism and the blind obedience to Sufi Sheikh that is demanded of their followers in many orders, were at the same time strongly, and consciously influenced by metaphysical Sufism of such classical Sufi authors as Maulana Rumi and Ibn Arabi. In part because of them, classical Sufi authors regained respectability among the Muslim intellectual elite. ${ }^{11}$

Therefore, Sufism has an important value for modern life, which is further away from social life. In the midst of the lifestyle of modern society that is individualistic and materialistic, Sufism can be one alternative to the achievement of a balancing human life of the world and the hereafter. According to William James in his book, The Variety of Religious Experience, one of characteristics of mysticism is integration with the Higher Reality. The mystical experience strengthens the total integration or unity with a transcendental reality or the Almighty, whether it be Yahweh (in

\footnotetext{
${ }^{10}$ Azyumardi Azra, The Origin of Islamic Reform in Southeast Asia: Networks of MalayIndonesia and Middle Eastern "Ulama" in the the Seventeenth and Eighteenth Centuries (Leiden: KITLV Press, 2004).

${ }^{11}$ Read Annemarie Schimmel, Gabriel's Wing: A study into Religious Ideas of Sir Mubamad Iqbal (Leiden: Brill, 1963).
} 
the Jewish tradition), the Lord God (for Christians), Allah (in Islam), Brahman, Sunyata or Tao (in Eastern Religions).

From the background that has been described above, this research would like to see how the phenomenon of movement of spirituality in the dimension of Sufism really powerful to improve the misfortune that previously infecting modern world. By studying these Sufi orders in a global context will bring attention to the world as a crossroad of ideas and spirituality, which continue to enlighten our life and times.

\section{Sufism and Civilization}

Even though Sufism covers a broad spectrum, practitioners and experts throughout Islamic history have generally accepted the following: "a doctrine or discipline whose goal is to remind humanity of their moral values as written in the Qur'an and Hadith." ${ }^{12}$ Sufism deals with morality and ethics. Sufism is as the name for the inner or esoteric dimension of Islam, which is supported and complemented by outward or exoteric practices of Islam, such as Sharia. The term Sufism embraces the philosophy and practices, which aim at direct communion between God and man, and those who practices Sufism called Sufis. Sufism then developed into the study of the spirit, which guides human behavior. It is also a form of Islamic mysticism that emphasizes spiritual closeness with God. From the Neo-Platonic tradition, the word mystic means "wordless contemplation or silence," derived from its Greek interpretation to "be silent in a thousand languages." This terminology was also used by the traditional Christians and originated as the Musticos, or "essential and esoteric spiritual interpretation" which meaning arose from religious texts in opposition to literal and exoterically derived interpretations.

The mysticism (Sufism) is an inseparable part of religion. Beginning in the $12^{\text {th }}$ century, Sufism was a mainstay for Islamic of

12 Alwi Shihab, Examining Islam in the West: Addressing Accusations and Correcting Misconceptions (Jakarta: PT Gramedia Pustaka Utama, 2004), 172. 
the social order for Islamic civilization, and since that time it has spread throughout the Muslim world, China, West Africa, and United States. Sufism has shaped literature and art for centuries, and associated with many of the most resonant pieces of Islam's "golden age." In modern times, the predominant view of Sufi Islam is one of "love, peace, and tolerance." It is important to note also that Sufi Islam thrived in civilizations, which had long and rich cultural history. Sufism emphasis is on inner being of a human person. Sufism flourished in Iraq, Iran, Egypt, Central Asian regions, India, and South East Asia as these regions had very rich civilizational history and culture and integrated themselves with local cultures, customs and traditions. Sufi orders as traditionally constituted have persisted in Muslim heritage throughout the world there has also been much innovation in the institutional arrangements through which study and practice of Sufism are carried out today. The growth and expansion of Sufism occurred at a time when Greek philosophy and scientific development were highly valued in Muslim societies. It coincided with extraordinary achievements in science and literature as many Muslim mystics produced exceptional works in philosophy, medicine, astronomy and the arts.

The golden period of Islam witnessed both flourishing of its inner and outer dimensions. Both dimensions informing one another built civilization that valued the notions of the governance and law as much as it did the inner workings of philosophy, spirituality and transcendence. It helped build a diverse population, willing to inquire and express Islam through many different languages, cultures and traditions.

The word civilization has more than one meaning. According to English Dictionaries the main meanings are (1) The state of being civilized, (2) culture, (3) cultural entity. Because of different meanings often are intermingled and descriptive used of civilization for different cultural entities in the world. Every civilization has it own unique core values. 
Civilization, on which the West prides itself so greatly, relies on some of material and industrial achievements, which multiply the chances of war and invasion. These are built on a very fragile moral and intellectual base, and on no metaphysical base whatsoever. The West is the greater danger from within, through feeble-mindedness, than from the outside, where it has to be admitted that its situation is not totally safe either. According to Samuel P. Huntington, the West is the only civilized civilization.

Samuel P. Huntington pointed out that the problem of the modern globalized society is that it tends to produce antagonisms. In the age of media all differences and antagonism of the modern world are becoming increasingly obvious. In this way the tensions of this world become more and more public and this brings the risk of clashes between different groups, nations, religious and ideological communities. ${ }^{13}$

Modern knowledge, is based on the concept of social historical space continuously constructed and deconstructed by the activities of the social actors, each group fights to impose its hegemony over the others not only through political power control of the state but also through a cultural system presented as the universal one.

On the contrary, the Qur'an insists on the necessity of man to listen, to be aware, reflect, penetrate, understand, and meditate. As is known, the Qur'an and Sunna are the fundamental sources of Islamic thought and civilization. All these verbs refer to intellectual activities leading to a kind of rationalization based on existential paradigms revealed with the history of salvation. Medieval thought derived from this an essentialist, substantialits, and unchangeable concept of rationality guaranteed by a Divine intellect. Therefore, based on this perspective, the Qur'an is the expression of the historical process, which led the small group of believers to power. This process is socially, politically and culturally, and psychologi-

${ }^{13}$ Read Samuel P. Huntington, The Clash of Civilizations and the Remaking of World Order (New York: Simon and Schuster, 2011). 
cally. Through it, the Qur'an presented as the revelation and received as such by the individual and the collective memory is continuously reproduced, rewritten, reread, and re-expressed in a changing social and historical space.

Sufism is a celebration of diversity and pluralism that every people have its own path of truth, beliefs and focus of reverence. Each of the great world religions, however, differs historically in terms of their attitudes, background, and position on how to deal with mystical experiences within their respective religious tradition. These words reflect the divine message to the Holy Prophet that there is no compulsion in religion. And also that of to every people have appointed ways at worship, which they observe. These values are the need of our times. Its message is beyond the confines of schools and sects, it's a spiritual quest that traces its origin from Holy Prophet and fundamental values of Islam, which laterally means peace.

Sufism is the voice of peace, co-existence, compassion and equality, a call to universal brotherhood. The values of harmony, welfare, compassion and love for human being are the foundation of just society. And these values are important to preserve and nurture diversity in our societies. Diversity is a basic reality of nature and source of richness of a society and it's should not because of discord. We need just not constitutional provisions or legal safeguards, but also social values to build an inclusive and peaceful society, in which everyone belongs, secure about his rights and confident of her future. Therefore, because there is no aspect of Islam that is not ethical at its base, experts are of the opinion that Sufism is the spirit and essence of its teachings. Indeed, the Qur'an itself emphasizes the importance of morality in human interaction with each other, with God's other creatures, and even in our interactions with God through prayer.

The humanity has established several religious beliefs, which gave meaning to people's lives. It raised the nations spirituality and strengthened their culture. I believe that God created man 
according to His own image and because of that, every human being has its own individual value and individual dignity, because we are all God's creations.

\section{Sufism and its Role in the Transformation of Society}

Generally, one strategy for repositioning Sufism in the modern world is to promote, in the words of Hamka (one of Indonesian's most prominent modernist reformers of the twentieth century), tasawuf tanpa tarikat, that is, Sufi teaching and some Sufi practices (tasawnf) without resource the Sufi orders (Tarikat). As a member of Indonesia's leading modernist organization, the Muhammadiyah, Hamka wished to encourage a modern Islamic ethos of rationality and personal responsibility that he thought was incompatible with tutelage from a Sheikh. In his popular book ${ }^{14}$ Tasawnf Moderen, first published in 1939 but still in print today, he give the expanding Muslim middle class and intelligentsia, who should take on the task of building a new nation, kind of do-it yourself guide to ethical reflection and the cultivation of Sufi spiritual virtues in the course of every day life.

The urban community used the tasawnf teachings to develop a new industry based on religion because of needed by the urban community. The Saturated urban community against the competition of life that has created a new Sufism market for new understanding of religion and spirituality and entered the area of mass communication and technology. Sutej $\mathrm{a}^{15}$ in his book explains that contemporary Sufism is basically rooted in the ranks of Rahman's neo- Sufism ${ }^{16}$ and the modern tasawnf that Hamka carried out. According to Hamka, modern tasamuf is a deep esoteric religious expression but not necessarily self-exile ('uحlah). NeoSufism emphasizes the need for self-involvement in society more

\footnotetext{
${ }^{14}$ Hamka, Tasawuf Modren (Jakarta: Pustaka Panjimas, 1983).

15 Suteja Ibnu Pakar, Tasawuf di Nusantara: Tadarus, Tasawuf, dan Tarekat (Cirebon: Akarasatu, 2016), 84-85.

16 Ibid.
} 
than in earlier Sufism. Neo Sufism tends to revive salafi activity and reinvigorate a positive attitude toward life. ${ }^{17}$

Carrying forward the spirit of Neo-Sufism reformism of the nineteenth century and adapting to twentieth century, the Naqshabandi community has discontinued rituals promoting extra ordinary religious experiences and stresses instead disciplining practices like sobbet to undergird work in the world with proper ethical comportment.

Sufism as a greatest tool for addressing global issues is not its tradition of social action. Attempts to deal with problems on the level of the problem may be succeed; more likely, they will not. We must look beyond external manifestations into the hearth of human beings. Dedicated practice of Sufism makes for an increasingly integrated and transformed human being.

This understanding can provide concrete evidence when looking at the phenomenon that occurred in the midst of the city today. There are Sufi institutions that have no direct roots to the tarikat and are mass-commercialized as well. Just for example, Indonesian Islamic Media Network (IMaN), Paramadina Islamic Studies Group, Takia Foundation, Tasawnf Islamic Center Indonesia (TICI), etc. These groups try to study and apply the teachings of Sufism in daily life in bulk; for example, Group Drikir, Taubah, Therapy Drikir. The face of Sufism in another form is done-and is very well-behaved- Emotional Spiritual Question (ESQ) under the leadership of Ari Ginanjar. It is said that the initial concept of ESQ, conducted by Nashrani in Europe and United Sates in anticipating the needs of the souls of local municipalities. ${ }^{18}$

Unfortunately, the things mentioned above shown more of the form of contemporary mysticism itself, a new form that takes place in the midst of urban society. If modern times are confronted with the spirit of returning to more positive forms and purity of

\footnotetext{
${ }^{17}$ Nurcholis Madjid, Islam Agama Peradaban: Membangun Makna dan Relevansi Islam dalam Sejarab (Jakarta: Yayasan Paramadina, 1995), 94.

${ }^{18}$ Suteja Ibnu Pakar, Tasawnf di Nusantara, 85.
} 
religious teachings, contemporary Sufism is the shifting of the form from the nature of individual tasamuf to the masses. The practice of Sufism would become more 'legitimate' when distributed in the media of communication and technology. Not to mention the fact that there are still many of those who have a tendency to practice neo- Sufism just make it as a 'mere activity'. Struggling with his daily life, which is then closed with a group of drikir. It's still with the unrelated pattern of intercourse between men and women, the habit of ghibah, dishonesty, materialistic-hedonic attitude, and others. Sufism entered into a part of living device with a new face that suits the taste of the era.

The new Sufis put forward a Sufi practice that leads to social piety as well as the individual. Sufi movements are only shown with the activity of drikir group or follow the suluk, but less touch on aspects of behavior and involvement of someone in social life. Therefore, the new Sufism emphasizes the need for greater self-inclusion in society, rather than the old Sufism. For example, below is a quote from a version of zubud or asceticism, one of the most important elements in Sufism derived from a book in Malay Jawi (Malay). ${ }^{19}$ Sufism is also about raising the consciousness of humanity. It's about healing the fear and hatred that sometimes arise in the human ego. The remedy is love and consciousness and they have to work together. Sufism helps people to step out of compulsions of hatred, mistrust and resentment. In other words, Sufism is about human transformation. ${ }^{20}$

Sufism strives to open space for tolerance, egalitarianism, and religious diversity. However, no version of Sufism can discard shariah without undermining Islamic Law. Lawless Sufism does little to improve a satisfying way of life for most Muslims. Law is indispensable for the construction and maintenance of an ordered society. Equally true, however, is the fact that law without

\footnotetext{
${ }^{19}$ Nurcholish Madjid, Islam Agama Peradaban, (Jakarta: Paramadina, 2008), 79.

${ }^{20}$ Alwi Shihab, Examining Islam in the West, 168-169.
} 
enlightened criticism leads to cruelty. ${ }^{21}$ Contemporary opposition to shariah in the West and denunciation of Sufism in some Muslim communities, both are misguided. The Sufis started different kinds of yoga practices in the form of exercises, which were believed to aid self-realization. This, according to them, amounted to God realization.

Over the centuries, the orientalists (Western Scholars who studied Islamic history and culture in the period of colonialism) have been censorious of shariah but appreciative of Sufism. The dichotomy continues until today. In nurturing this dichotomy, some Western scholars are anti-Shariah, some are unacquainted with Islam, some are motivated to moderate what they perceive as the "excesses of shariah," such as persecution of religious minorities, subjugation of women, and imposition of harsh criminal punishment. ${ }^{22}$

Unfortunately, scholars bereft of mysticism are incapable of understanding the Sufi ways because intellectualized scholarship can barely see beyond the walls of argumentation. ${ }^{23}$ Sufism offers the collected wisdom transmitted down through the centuries by which one can proceed towards a transformed mentality, deeper love, positive character traits, and courage to work for improvement of society.

In Islam, Spirituality is an inseparable part of human consciousness toward God and at the same, consciousness toward their responsibility to live according to His will and guidance. In others words, the principle of taubid represents the core of God's message. ${ }^{24}$ It is Islamic spirituality in all its aspects and dimensions, and the central manifestation of taubid is the Qur'an; it is the source of all Islamic spirituality.

${ }^{21}$ Damanhuri, Akblak Tasawuf, 80-83.

22 Alwi Shihab, Examining Islam in the West, 182-188.

${ }^{23}$ Damanhuri, Akblak Tasawnf, 83-84.

${ }^{24}$ Alwi Shihab, Examining Islam in the West, 189 
The subsequent marginalization of Sufism can be seen predominantly as by a product of two distinctive ideologies emerging from the twentieth century, namely, Muslim modernism and revivalist schools of thinking for Muslim modernists like Muhammad Abduh.

For many early Sufis, it was asceticism and simplicity of life that were the key to a true following of Islam. Others have emphasized love as the central idea and understand the Sufi path as one leading to a union of love with God, the Beloved. For others, Sufism is a voluntarist path by with the believer, by concentrating on virtue and moral behavior, comes into a union of will with God, a state in which the mystic no longer has an independent will of his or her own, but seeks only to do the will of God.

\section{Sufi and Modern Life}

Contemporary Muslims are suffering from a lack of confidence and faith in themselves because they cannot face the challenges of the modern world. We are facing new millennium, the humanity faces new challenges, challenges of peace, solidarity and love. The fact of complexity in modern society that leads to the thirst for the values of spirituality sees the neo- Sufism movement (the new Sufi), which puts the balance of world life and the hereafter forward. Break away from the blind ascetic life that takes off the social world in private life. The world is a part of human life that cannot be separated, so to reach the hereafter the world becomes an important media that cannot be ignored.

The discussion on Sufism and modernism will offer new and refreshing perspectives on this important resurgent by demonstrating revelations between Sufism and the currents brought by Muslim reformists. It will also seek to explore the important presence of Sufi practices and ideas in all aspects of life. There has been considerable influence of Sufi on contemporary Muslim societies in terms of intellectual, economic and political 
lifestyles contrary to the early theories of modernization of the Muslim societies.

Many changes of the Western civilization have brought to the world that produced enormous effects on the modern life. However, it remains an interesting fact that the concepts of Sufism can be applied to improve our understanding on the human state in the present age. In terms of modern religion, the traditionally influenced Muslims have always maintained hat Sufism is soaked into opposing the dogma and spirits of Islam which can merely be considered to be a heresy or just separate form of religion which is inadmissible for the so call genuine believers. This incompatibility between Islam and Sufism can be traced to the pantheistic ideas found in the thoughts and mysticism of the destruction of Islamic belief of God. However, the image of pre-modern Sufism, Barbara van Schlegell has characterized tasawuf before the modern era as "the one cultural and intellectual constant that bound together elite and common Muslims throughout the Muslim world". ${ }^{25}$

The influx of better educated and professionally qualified people into classically founded Sufi orders has enabled some of these orders to undergird the informal relationship linking the sheikh to his spiritual deputies and initiates with a parallel bureaucratic structure, extending the organizational changed initiated by the earlier Neo Sufism movement.

Neo-Sufism is a doctrine of the esoteric values of religious practice that encourage people to engage in society actively and pay good attention to their social problems. Neo-Sufism affirms a balanced religious life between worldly and heavenly life because they are very important to every Muslim. Therefore, Neo-Sufism, as described by researchers, tried to address the concept of tawazun or balanced as its basis. Sufis orders as traditionally constituted have persisted in Muslim heritage societies and in diaspora communities throughout the world, there has also been much

\footnotetext{
${ }^{25}$ Barbara Van Schlegel, "Translating Sufism," Journal of the American Oriental Society 122, No. 3, (2002).
} 
innovation in the institutional arrangements through which study and practice of Sufism are carried out today.

The phenomenon of spiritual movement that emerged in Aceh put forward the common ziker (literally remembrance) or chanting of God's names and invites the life of zubud, it is not yet known how this new Sufi movement, whether more directed to classical or modern Sufism. Zikr is a spiritual practice, which is designed to make God present in a person. Even in a high intensity, a sufi can feel not only close to Allah, but also feel being united with Him (ittihad). It also functions as a soul therapy. The development of postmodernism society is no longer sufficient to be filled by merely provided the principal worship, people need for more intense experiences in searching for the meaning. This is actually provided by Sufis.

Tasawn study outside the Sufi orders also has been made available to well-educated Indonesian urbanites by university and religious education institutes, such as the Paramadina Foundation associated with the late Nurchalish Majid, and through formal study programs offered by the leading mosques. At the university level, Professor present tasawnf as one of the classic scholarly disciplines of Islamic knowledge.

Saluyo $^{26}$, with a text entitled Finding the Meaning of Life with the Sufi Way in the Modern Era, aims to find out the Sufi behavior in the modern era related to the meaning of life. The question is whether a person who practices Sufi behavior is able to find meaning in life. The problem of life in the modern era is many challenges and problems facing everyone. One way a person finds meaning in life by using spiritual and religious beliefs. Spiritual possessed of a person will result in worship, good deeds, and noble character. This view is the view of the voters of the path of Sufi life. One of the practices of Sufi behavior is fasting, meditation, and ethics. Sufi behavior is a representation of the spiritual

\footnotetext{
${ }^{26}$ Saluyo, "Mencari Makna Hidup dengan Jalan Sufi di Era Modern," Esoterik: Jurnal Akblak dan Tasawuf, Vol. II, No. 1, (2016).
} 
freedom that gives birth to great tranquility, purification, and happiness with God.

Muslim in the twentieth and twenty first centuries have found new ways to promote Sufi teachings and practices without recourse to the Sufi orders, so also have offshoots of some of the orders radically altered what they teach as Tasawnf. Sufism ought to be just as important today as it has ever been before. Being a way of purifying the soul a necessity for each new generation. This is because the traditional form of tasawnf, which has been shaped by many historical accretions, has no great appeal for the modern educated mind. The need to modernize Sufism, couching it in the contemporary idiom, and explaining its ideology in a way that should address the present-day individual, whose major concern is as much with intellectual development as it is with purification of the soul. Therefore, Sufism should necessarily be linked with real events and its objectives expressed in a scientific manner.

In this modern world, Muslims need to develop, deepen the life of faith. A deeper spirituality, with prayer at its core, will constitute an important part of the characteristically religious reckoning with secularity. Religions are not saved by mental efforts alone. We must live as faithful people, we must strengthen our style of dealing with modernity by living within the parameters of faith, by actively striving for a genuine religiosity that seeks and find resources for honest, including intellectually honest, living in a difficult age. ${ }^{27}$ Sufism, the generally accepted term for the Islamic mystical tradition, is seen by many as offering such food for the spirit. Sufism is not a single clearly defined movement, but an interrelated network of ideas and practices aimed at a deeper understanding and faithful pursuit of the Qur'anic messages. NonMuslim scholars as well as Sufis themselves.

\footnotetext{
${ }^{27}$ Read Shabbir Akhtar, "Islam and the Challenge of the Modern World," in Charles Kurzman (ed.), Liberal Islam (Oxford: Oxford University Press, 1998).
} 


\section{Conclusion}

The science of nature is a human endeavor to understand nature, and the science of religion is a human endeavor to understand religion. Religion thus continues to be an important identity for its believer in society. Religious belief and practices have a large impact on the personal lives and influence public life on a daily basis. All social relations were inevitably and legitimately engaged with religious tradition and practices. The possibility of religion in a modern world can be felt through altered functioning of religion.

When the spiritual love of Sufism, not the violent force of terrorism, flows across the border, this region will be the paradise on earth. Peace is primarily peace of mind and heart, a state in which there is orderliness in one's relation with God in the first place and with others in the second place. As a holistic and transcendence philosophy, Sufism provides Muslims greater latitude to engage in debates about increasingly divisive politics shaping their societies, while confronting the stringent and narrowing ideologies of fundamentalists.

Therefore, Sufism has an important value for modern life, which is further away from social life. In the midst of the lifestyle of modern society that is individualistic and materialistic, Sufism can be one alternative to the achievement of a balanced human life of the world and the hereafter. It is also Sufism as a spiritual doctrine and practice has gained attractive to many Muslims in the modern world as an alternative to the political and puritan of Islam. Also, the Sufism can certainly help to inspire a new generation of Muslim followers eager to express their inner convictions and reconnect with their lost heritage. Sufism also can serve as a critical reminder of its deep commitment to help Muslim consciousness against the ever-growing materialism and consumerism plaguing the modern world. Therefore, the Sufism has a significant role in not only understanding modernity but also enjoying the fruits of modernism. 


\section{Daftar Pustaka}

Azra, Azyumardi. The Origin of Islamic Reform in Southeast Asia:

Networks of Malay-Indonesia and Middle Eastern "Ulama" in the the Seventeenth and Eighteenth Centuries. Leiden: KITLV Press, 2004.

Banton, Michael. Anthropological Approach to Study of Religion.

London: Tavistock, 1966

Berger, Peter L. The Sacred Canopy: Elements of A Sociological Theory of Religion. New York: Anchor Books, 1990.

Damanhuri. Akblak Tasawuf. Banda Aceh: Yayasan Pena, 2010.

Hamka. Tasawuf Modren. Jakarta: Pustaka Panjimas, 1983.

Heriyanto, Husin. Paradigma Holistik: Dialog Filsafat, Sains, dan

Kebidupan Menurut Shadra dan Whitehead. Jakarta: Teraju, 2003.

Huntington, Samuel P. The Clash of Civilizations and the Remaking of

World Order. New York: Simon and Schuster, 2011.

Kurzman, Charles (ed.). Liberal Islam. Oxford: Oxford University Press, 1998.

Madjid, Nurcholis. Islam Agama Peradaban: Membangun Makna dan Relevansi Islam dalam Sejarah. Jakarta: Yayasan Paramadina, 1995.

Nye, Malory. Religion the Basics. Routledge: London, 2003.

Pakar, Suteja Ibnu. Tasamuf di Nusantara: Tadarus, Tasawnf, dan

Tarekat. Cirebon: Akarasatu, 2016.

Saluyo. "Mencari Makna Hidup dengan Jalan Sufi di Era Modern." Esoterik: Jurnal Akblak dan Tasawnf, Vol. II, No. 1. 2016.

Schimmel, Annemarie. Gabriel's Wing: A study into Religious Ideas of Sir Mubamad Iqbal. Leiden: Brill, 1963.

Schlegel, Barbara Van. "Translating Sufism," Journal of the American Oriental Society 122, No. 3. 2002.

Sells, Michael A. Early Islamic Mysticism. New York: Paulist Press, 1996. 
Shihab, Alwi. Examining Islam in the West: Addressing Accusations and Correcting Misconceptions. Jakarta: PT Gramedia Pustaka Utama, 2004.

Syukur, Amin. Menggugat Tasammuf. Yogyakarta: Pustaka Pelajar, 1996. 